\title{
HOW MUCH IS TOO MUCH? \\ THE INFLUENCE OF PRESCHOOL CENTERS ON CHILDREN'S SOCIAL AND COGNITIVE DEVELOPMENT
}

Susanna Loeb

Margaret Bridges

Daphna Bassok

Bruce Fuller

Russ Rumberger

Working Paper 11812 
NBER WORKING PAPER SERIES

\title{
HOW MUCH IS TOO MUCH? \\ THE INFLUENCE OF PRESCHOOL CENTERS ON \\ CHILDREN'S SOCIAL AND COGNITIVE DEVELOPMENT
}

\author{
Susanna Loeb \\ Margaret Bridges \\ Daphna Bassok \\ Bruce Fuller \\ Russ Rumberger \\ Working Paper 11812 \\ http://www.nber.org/papers/w11812
}

\author{
NATIONAL BUREAU OF ECONOMIC RESEARCH \\ 1050 Massachusetts Avenue \\ Cambridge, MA 02138 \\ December 2005
}

The views expressed herein are those of the author(s) and do not necessarily reflect the views of the National Bureau of Economic Research.

(C2005 by Susanna Loeb, Margaret Bridges, Daphna Bassok, Bruce Fuller, and Russ Rumberger. All rights reserved. Short sections of text, not to exceed two paragraphs, may be quoted without explicit permission provided that full credit, including (C) notice, is given to the source. 
How Much is Too Much? The Influence of Preschool Centers on Children's Social and Cognitive Development

Susanna Loeb, Margaret Bridges, Daphna Bassok, Bruce Fuller, and Russ Rumberger

NBER Working Paper No. 11812

December 2005

JEL No. I2, I3

\begin{abstract}
$\underline{\text { ABSTRACT }}$
Previous research has demonstrated that attending center care is associated with cognitive benefits for young children. However, little is known about the ideal age for children to enter such care or the "right" amount of time, both weekly and yearly, for children to attend center programs. Using national data from the Early Childhood Longitudinal Study (ECLS-K), this paper asks whether there are optimal levels of center care duration and intensity and whether these levels vary by race or income. We consider pre-reading and math skills as measured by assessments administered at the beginning of kindergarten, as well as teacher-reported social-behavioral measures. We find that on average attending center care is associated with positive gains in pre-reading and math skills, but negative social behavior. Across economic levels, children who start center care between ages two and three see greater gains than those who start centers earlier or later. Further, starting earlier than age 2 is related to more pronounced negative social effects. Results for center intensity vary by income levels and race. For instance, poor and middle-income children see academic gains from attending center intensively (more than 30 hours a week), but wealthier children do not; and while intense center negatively impacts Black and White's social development, it does not have any negative impact for Hispanic children.

Susanna Loeb

224 CERAS, 520 Galvez Mall

Stanford University

Stanford, CA 94305

and NBER

sloeb@stanford.edu

Margaret Bridges

mbridges@berkeley.edu

Daphna Bassok

dbassok@stanford.edu

Bruce Fuller

b-Fuller@uclink4.berkeley.edu

Russ Rumberger
\end{abstract}




\section{Introduction}

Young children - at least those from low-income families - benefit from exposure to preschool or child-care centers in terms of cognitive growth and school readiness. Experiments such as the Perry Preschool or the Abecedarian Project have long shown sustained effects on cognitive growth for children from poor Black families (Campbell et al., 2002). Larger public programs, such as the Chicago Child-Parent Centers, also show encouraging results, as do center-based programs of naturally varying quality spread across different states (Loeb et al., 2004; Reynolds \& Temple, 1998).

What we don't know is whether the effects of preschool centers vary by intensity of exposure and for children from different backgrounds. This paper extends recent work by Magnuson, Ruhm, \& Waldfogel (2004) to consider the effects of different child-care arrangements on children's cognitive and social proficiencies at the start of kindergarten, estimating the effects of the duration and intensity of children's participation. We also focus on how effects vary across children from different social classes and ethnic groups. These issues are directly germane to debates over whether extending free preschool to all children is a costeffective policy, whether full or half-day programs are advisable, and which groups of children would likely benefit from them.

Our analyses, drawing on data from the Early Childhood Longitudinal Study (ECLS-K), starts by asking the question: does exposure to center care in the years before kindergarten improve children's cognitive and social-behavioral outcomes at kindergarten entry? Next we ask how the relationships between center care and development vary for children from differing income and ethnic groups. Finally, we focus on the effects of the intensity and duration of center attendance - as measured in years, months per year and hours per week-on child outcomes. Never before has the field been able to test these relationships with a large and nationally representative sample of young children with such rich background data on their families.

Does exposure to center-based care in the year before kindergarten improve children's outcomes in kindergarten? Almost two-thirds of all four-year-olds now attend center programs before starting kindergarten (U.S. Department of Education, 2003), although the length and intensity of their exposure, and the quality of these local programs, vary dramatically. Exposure to these diverse preschool programs, often called center-based child-care programs, benefits children's cognitive development, and appears to be one of the most effective 
interventions for advancing poor children's learning (Heckman, 2000; Shonkoff \& Phillips, 2000). The cognitive benefits appear to be modest to strong for some groups; however researchers estimating effects on children's social-behavioral outcomes have found largely negative social effects (NICHD ECCRN \& Duncan, 2003).

\section{How does the relationship between center-based care and development vary by}

family income and ethnicity? Disparities in early cognitive proficiencies are starkly evident across social class and ethnic groups, as children enter kindergarten. The difference between Black and White children in their early language and cognitive development is equal to the approximate amount that children learn during two to three months of kindergarten (Reardon, 2003). English-proficient Hispanic five-year-olds in California score about 0.38 of a standard deviation $(S D)$, or about three months, behind White youngsters in pre-reading and math skills (Rumberger and Arellano, 2003).

Similar early learning gaps exist between children from poor and affluent families. Children in the lowest socioeconomic group are several months behind their middle-class peers in pre-reading and pre-math skills at kindergarten entry. This gap almost triples when poor children are compared to the most affluent fifth (Bridges et al., 2004). The disparities between groups often grow even larger over the course of children's schooling (Fryer \& Levitt, 2004).

Attending high-quality child care appears to boost children's developmental trajectories, leading to speculation about the possibility of its closing achievement gaps (Barnett, 1995; Bridges et al., 2004). Researchers have compared various care arrangements - including centers, Head Start preschools, licensed homes, or individual caregivers - to determine which might hold the most promise for improving cognitive and social-behavioral outcomes. Center programs appear to offer the most benefits for poor children (Loeb et al., 2004), with participation in carefully controlled and expensive, "boutique" preschools generating immediate and long-term benefits (Barnett, 1995; Campbell \& Ramey, 1995). Evidence for Head Start, distinguished by the poor children it serves and by its centralized regulations, is mixed (Garces et al., 2002).

If exposure to center programs boosts poor children's development, this intervention strategy could help to close the achievement disparity. This leads to the empirical question of whether or not the effects of center exposure vary across social-class and ethnic groups. However, center-based programs appear to raise cognitive proficiencies for middle-class children as well as for children from low-income families (Magnuson et al., 2004ab). An analysis for the 
California sub-sample of the ECLS-K data also found significantly higher cognitive proficiency levels for English-proficient Hispanic children from middle-class homes when they had attended center-based programs in the year before kindergarten (Bridges et al., 2002).

Yet, several studies indicate that children from disadvantaged homes may exhibit the greater gains from participating in center-based programs (Burchinal et al., 1997; Campbell \& Ramey, 1994; Magnuson et al., 2004a). Center programs also may benefit English-language learners differentially, given that these children are less likely to experience the types of early literacy practices in the home which have been found to facilitate early language and cognitive development (August \& Hakuta, 1999; Snow, Burns, \& Griffin, 1998).

Differing rates of access to center programs continue to concern policy makers and hold implications for taking into account selection processes when estimating effects of centers on child development. Participation rates in center programs rise with social class: children from affluent families are much more likely to enroll than children from other SES groups (O'BrienStrain et al., 2003). More than 70 percent of upper middle-class children attend center-based programs before starting kindergarten, compared with 45 percent of those from low-income families (Hofferth et al., 1995). However, expansion of Head Start and state preschools has dramatically increased participation by children from poor families since the 1960s (Smith et al., 2003). In fact, it may be that working-class families have less access to centers than their poor counterparts, because they earn just above income eligibility cutoffs for subsidies yet they cannot afford high fees (Fuller et al., 2004).

Ethnic disparities in preschool access also remain stark. Hispanic parents enroll their children in centers at a rate 23 percentage points below the rate for Black children, and 11 percent below Whites, even after taking into account maternal employment status (Liang et al., 2000). Asian American children participate in preschool at substantially lower rates than Whites or Blacks, though they show quite high pre-reading and math proficiencies (NCES, 1998).

\section{What are the effects of the intensity and duration of center attendance on children?}

A concern for parents and policy makers is how much time children should spend in preschool or child-care programs; yet, little empirical work has focused on the effects of the length of exposure to center programs between the ages of two and five years, nor on the intensity of exposure in terms of hours per day. The effects of different child care arrangements are likely based in part on the amount of time children are exposed to them. Exposure can be seen as a 
"dosage" effect and can be conceptualized as the age at entry and intensity of attendance. Children entering at younger ages or attending for more hours per week may exhibit greater benefits (or detriments) than those with later or less exposure. Little is known about the amount of exposure that maximizes cognitive gains or guards against detrimental social-behavioral effects.

Research to date on cognitive outcomes generally shows that earlier intervention is best, at least for children from poor families (Shonkoff \& Phillips, 2000). Preschool may be atypical of interventions, however, as it entails both separation from parents and exposure to variable yet potentially enriched learning environments. The evidence on the effects of early entry into child care is mixed. Entering center-based care in infancy may not be a detriment to poor children's cognitive outcomes (Vandell \& Ramanan, 1992); but it may for White or middle-class children (Han, Waldfogel, \& Brooks-Gunn, 2001; NICHD ECCRN, 2002). Later entry appears to diminish these potential negative effects on cognitive development and in fact provide benefits. Initial work with the California sub-sample of the ECLS-K data indicates that starting centerbased care at age three provides a boost to children's early reading and math skills, in comparison to starting later (Bridges et al., 2004). Clements, Reynolds, \& Hickey (2004) echo this finding for children attending Chicago Child-Parent Centers (CPCs), with two years of preschool—starting at three-providing more benefits to children at school entry than just one year, although these increases were no longer significant in first grade.

In contrast, entering child care early may hold negative social-developmental outcomes, including disruptive and aggressive behavior in centers and later in school (Belsky, 2002; Han et al., 2001). These negative effects on social behaviors also have been observed for children who begin center programs later (age four), and they may be associated with the cumulative amount of time in child care, rather than the age of initial entry (Colwell et al., 2001). For example, children spending longer hours or more months in center care each year exhibit greater problem behaviors, including elevated levels of aggression and less effective impulse control (Bates et al., 1994; NICHD ECCRN, 2003). Belsky (2002), using the largely middle-class NICHD sample, found a linear and positive relationship between hours in child care and externalizing behavior.

Han et al. (2001) examined related questions about time in child care and behavior problems with the National Longitudinal Survey of Youth. They found that White children whose mothers worked within the first nine months of their lives, and thus presumably attending 
non-maternal care, displayed higher rates of externalizing behaviors by age seven or eight. Given that this association is between maternal employment, not child care per se, and children's externalizing behavior, it may be the long separation from parents and not attending child care which increases behavior problems.

While this evidence suggests that time spent in center programs may increase behavioral problems, it is not clear that these effects are seen across children from different backgrounds. Clements, Reynolds, \& Hickey (2004) found positive effects on the social-emotional and behavioral outcomes of children in the Chicago CPC program, which entailed children's participation of about 15 hours per week. The benefits were significant and sustained over time: participants had better behavioral outcomes in school and lower rates of delinquency and criminal behavior years later. While these results are encouraging, this intervention was conducted with very poor children and had more comprehensive services than standard center programs offer, including home-visiting components and more intensive parent involvement.

The present study contributes to this literature in several ways. In addition to using a representative sample of English-proficient U.S. children, it assesses the duration effect of center-care experiences to ask, what is the optimal age for children to enter center programs? Second, it looks at the intensity effect, asking whether there is some number of hours per week of attendance that holds an optimal effect. Third, it examines both of these effects by the income of the child's family and by racial groups, asking whether center care experiences are more or less important for children from different groups. All three of these questions are central to the current debate over universal preschool.

\section{Data}

Our analysis uses data from the ECLS-K. These data were drawn from interviews with a nationally representative sample of parents with young children, along with direct assessments of their five year-olds and interviews with kindergarten teachers. We analyzed data for 14,162 children who entered kindergarten for the first time in 1998. We excluded children with missing scores on any of the assessments and children with no child care information. ${ }^{1}$

\footnotetext{
${ }^{1}$ We dropped students who were missing child care information $(3,190)$, children who were not first-time kindergarteners (867), or missing any one assessment $(3,041)$. We ran specification checks with missing values imputed using best-subset regression and found no meaningful difference in the results of interest.
} 
Child Care Measures. In the fall of kindergarten, parents were asked a series of questions regarding their child's care arrangement in the previous year. Based on their responses, we categorize children into four mutually exclusive child-care types: (non-Head Start) center program, Head Start program, parental care, and non-parental care. The non-parental care group includes care by non-parent relatives and non-relatives such as a babysitter. Though parents were asked to specify whether their child attended a day care center, a preschool, a nursery school, or a pre-K program, we were concerned that the differences between the four center types were difficult for parents to distinguish. We therefore created a single center care group that includes children who went to any type of child care center with the exception of Head Start. If parents indicated that their child received care at multiple settings, we coded them as follows: if a child attended center care in combination with parental or non-parental care, he/she was placed in the center care group. Similarly, if a child attended Head Start in combination with parental or non-parental care, he/she was placed in the Head Start group. Finally, if a child participated in center care and a Head Start program, we placed him/her in the group in which she spent more hours per week. ${ }^{2}$

To test whether the amount of center exposure made a difference in children's outcomes, we created a series of age of entrance and intensity variables. To get at the impact of early entrance, we created indicator variables for the child's age at first entry to center care (age 0-1, $1-2,2-3,3-4,4-5$, greater than 5 , and unknown). ${ }^{3}$ We also created two intensity variables: the first dichotomous variable indicates whether the child attended center care for 15 to 30 hours per week and nine months out of the year; the second, raises the weekly hours to at least 30 hours per week and at least nine months. ${ }^{4}$ Approximately 21 percent of children who use a center as their primary care type are in the first, moderate intensity, group; 30 percent are in the high intensity group. While we created these distinctions in keeping with the typical half-day program and the

\footnotetext{
${ }^{2}$ If center hours and Head Start hours were equal, we considered the child a Head Start attendee. NCES independently confirmed Head Start attendance, so we assigned to the center care group those who reported attending Head Start but were not confirmed as attending Head Start. For these children, we assumed that the parent-reported age at Head Start entry as well as the weekly hours variable referred to center care provision. ${ }^{3}$ Parents were asked to indicate their child's age on initial entry to a particular type of care. However, age at entry does not necessarily imply continual enrollment: a child may have entered center care at age two for several months, withdrawn, and then re-entered at age four. The data do not include parents' reports on continuous usage of care.

${ }^{4}$ The majority of children who attended a center for more than 15 hours a week also attended for 9 months per year or more $(78 \%)$.
} 
typical full-day program, this categorization is not the only one worth considering; therefore we ran a number of specification checks with alternative definitions of intensity.

Child Outcomes. NCES field staff conducted one-on-one child assessments, in the fall of kindergarten, to measure reading and mathematics ability. The reading assessment measures a variety of skills including print familiarity, letter and word recognition, beginning and ending sounds, rhyming sounds, vocabulary, and comprehension. The math test evaluates each child's knowledge of numbers as well as their spatial sense and problem solving abilities (Early Childhood, 1998-99). The assessments in each subject area were administered in two stages; the first involved a routing test, and the second involved items at the appropriate difficulty level. In our analyses we used standardized T-scores. These scores are transformations of raw scores that have been rescaled with a mean of 50 and a standard deviation of 10 . T-scores are normreferenced measures of early learning for specific domains and provide an indicator of how each individual child performs relative to the national average.

We also examined children's social-behavioral skills and problems as reported by kindergarten teachers for each child. Teachers were asked to evaluate the social skills of the sampled children in their classroom on a scale from one to four with respect to their motivated engagement of learning activities, self-control, and a variety of interpersonal skills. Using factor analysis we created a composite score that combines measures of self control, interpersonal skills, and externalizing behavior (Cronbach's alpha of 0.87 ). The behavior score is standardized with mean of zero and a standard deviation of one, so reported coefficients are readily interpretable as effect sizes.

Other Predictors and Control Measures. In order for the results to be comparable with Magnuson, Ruhm, \& Waldfogel (2004), we use the same set of ECLS-K variables as controls for family background characteristics. In order to capture neighborhood effects, we also include a set of zip code level variables, aggregated from the long form of the 2000 Decennial Census. ${ }^{5}$

\footnotetext{
${ }^{5}$ ECLS variables were: age, gender, birth weight, weight, height, race/ethnicity, number of children, family structure, urban, region, mother's employment , parental education/employment, English, income-to-needs, expectations, importance of skills, choice of location, home learning activities , number of children's books in home, number of music tapes, CDs, or records in home, reading, school activities, parenting stress/depression, spanking, eating habits, computer, TV, visiting, other non-school activities, neighborhood. Zip code data from the 2000 long form of the decennial census were: total population, \% Black/Pacific/Other/Asian/Hispanic/Mixes, \% Urban, \% Native, $\% 5$ and under, $\%$ children under 5 in poverty, $\%$ population over 16 in the labor force who are unemployed, $\%$ of children 0-6 living with single mothers/fathers, \% Hispanic, $\%$ of women with children 0-6, in the labor force/unemployed, \% households in which Spanish is sometimes or always spoken, \% women over 25 with less than a HS diploma, \% households in which a language other than English is sometimes or always spoken, \%
} 
Table 1 gives the means and standard deviations of a subset of the variables for the full sample and separately for youngsters attending each type of child care. We see that 64 percent of the children attended center care, compared with 17 percent in parental care, eight percent in Head Start and 12 percent in other non-parental care. Children in Head Start were somewhat more likely to come from the South and much more likely to be Black. Center programs are more evenly distributed across the country, but Hispanic children are less likely to attend. Large differences in socio-economic status are evident across child care types, as well.

Children in Head Start, not surprisingly, had lower birth weight, were more likely live in a single-parent family, have parents without high school degrees, and have participated in WIC, compared with all other children in the ECLS sample. Parents who provided the sole care for their children were, not surprisingly, less likely to be single parents and less likely to work full time. Children in center care were more likely to speak English only at home and have more highly educated parents. Children with other non-parental care were more likely to come from families in which the mother works full time.

In addition to these differences in social status, children in different care settings differ in their home lives. For example, children in Head Start have the least number of children's books in their home, while those in other centers have the most. Children in Head Start watch the most television, while those in centers watch the least. Children in Head Start are most likely to be spanked, while those in center care are least likely. Parents of children in Head Start are least likely to attend a parent-teacher conference during kindergarten or volunteer at school; those in center care are most likely.

\section{Method}

These prior differences in family background must be taken into account as we estimate the discrete effects of exposure to center programs on children's social and cognitive development at the start of kindergarten. The heart of our analysis relies on the rich measures of children and families available in the ECLS-K to adjust for differences across child care settings using a regression framework. Equation 1 summarizes this approach:

women over 25 with a HS diploma, \% households that are linguistically isolated (no one over 14 speaks English), \% of women over 25 with a BA or more, $\%$ of family households with 6 or more members, $\% 3$ and 4 year olds in preschool/nursery school, \% non-citizen population, \% 3 and 4 year olds in PUB preschool/nursery school. Full details are available from the authors. 


$$
Y_{i z s}=\alpha_{0}+C_{i z s} \alpha_{1}+X_{i z x} \alpha_{2}+Z_{z s} \alpha_{3}+\pi_{s}+\varepsilon_{i z s}
$$

The outcome (Y) of child (i) in zipcode (z) and state (s) is a function of child care type (C), child and family characteristics (X), demographic attributes of the zip code in which the child resides $(Z)$, state fixed effects $(\pi)$, and a random and normally distributed error term $(\varepsilon){ }^{6}$ Child care type in the base model is a series of three dummy variables for center care, Head Start and other non-parental care in comparison to parental care. In the models assessing duration, child care type is expanded to include the duration of center care.

The center program dummy variable in this case is replaced by seven dummy variables measuring starting center care at age zero to one year, one to two years, two to three years, three to four years, four to five years, greater than five years, and start date unknown. In the model assessing intensity the center care dummy is supplemented by mutually exclusive dummy variables for attendance of 15 to 30 hours per week for at least nine months per year and for attendance of at least 30 hours per week for at least nine months per year.

Notwithstanding family background controls, it is easy to mis-specify a regression model. For example, many regression models assume a linear relationship among variables when the relationship is meaningful but non-linear. The bias created by this misspecification can be larger when there is less overlap across treatments, as is the case here. For example, we may estimate the effect of income on child outcomes using data points that fall mostly within one income range; the group of children in this income range will be most important for determining the estimate. If children in a particular care type (for example Head Start) have much different income then we may apply estimates that are inaccurate for this group. We mitigate the potential bias from misspecification by using multiple dummy variables instead of continuous variables for measures such as education and income. In addition we run a separate analysis using statistical matching of children across child care type. We use kernel matching, a non-parametric matching approach that creates matches for the treatment using (biweight) kernel weighted averages of those not in the treatment (Heckman, Ichimura and Todd 1998). ${ }^{7}$

\footnotetext{
${ }^{6}$ Most analyses using ECLS-K require clustering by school for properly estimating standard error. However, because child care attendance occurred prior to schooling, clustering is unnecessary in this case. Specification checks using clustering at the school level show no difference in the statistical significance of estimated effects. ${ }^{7}$ This gives very similar results to predicting treatment probabilities, $\mathrm{P}$, as a function of all the other right-hand-side variables in Equation 1 using a probit, and then creating a weight of 1 for those in the treatment and P/(1-P) for those not in the treatment.
} 
In addition, we reduce the possibility of omitted variable bias in our analyses by using an unusually rich set of control variables. We also performed an instrumental variables estimation, based on measures of child care supply, with the hypothesis that supply factors would influence parents' selection of child care but be unrelated to other aspects of family background that would directly affect child outcomes. We obtained counts of child care establishments and community organizations at the zip code level. Given the extensive set of zip code level controls from the census in the second stage, we posited that these measures would predict center use but not child outcomes. Due to our concern that child care establishments could act as a proxy for unmeasured tastes, we also ran specifications that did not include this measure.

To supplement these zip code level measures, we obtained a number of state-level measures to capture state intervention. We created three variables that measure state-level child care spending: each state's 1999 spending on pre-kindergarten programs, Head Start, and the child care component of their Temporary Assistance to Needy Families (TANF) initiative was divided by the number of children under 5 years of age living in poverty. ${ }^{8}$ Finally, we included measures from Schulman and Blank (2004) for the income cutoff for state child care assistance both as a level and as a percentage of the state median. These variables were meant to capture each state's commitment to child care provision, particularly for poor children. We estimated a linear probability model in the first stage. Unfortunately, while the difference between the IV estimates and the OLS estimates were not statistically significant and the IV estimates were in the same direction as the OLS estimates, the standard errors were too large to draw any meaningful conclusions from the IV analyses.

We first present the model for our full sample and then show results separately by the children's race and family economic status. Our full sample includes all racial groups. However, due to limited sample sizes, we only present results for the White, Black and Hispanic sub-samples. It is important to note that reading assessments were only administered to students deemed minimally proficient in English. Students who could not pass an oral proficiency screener in English were not given the full assessment in pre-reading skills. Therefore, our results for Hispanic students are only generalizable to those students whose English ability was above a threshold. We utilize two approaches to define economic status. As a broad measure of

\footnotetext{
${ }^{8}$ Head Start and state pre-K spending figures are from Blank, Schulman, \& Ewan (1999). TANF spending data, for 1999, are from http://www.acf.dhhs.gov/programs/ofs/data/tableB_1999.html. The share of population under five years of age in poverty is taken from long form of the decennial census.
} 
economic well-being, we group together children from families in the lowest income-to-needs ratio quartile, the middle half, and the top quartile. We also consider a stricter measure of poverty that includes only those children whose income-to-needs ratio is less than 0.5 or children whose mother and father have never completed high school. This group represents about 8 percent of the full sample.

\section{Results}

Table 2 presents a model that predicts child outcomes based on child-care type and the set of prior family attributes, parental practices, zip code-level demographics, and state fixed effects. (Full details of the estimates are available from the authors). The results provide evidence that center care improves children's reading and math skills but also increases behavioral problems relative to parental care. For the full sample, center care attendance increases reading skills by 1.1 points. The standard deviation in reading is 10.0; thus the point estimate implies a 0.11 standard deviation increase. The results are very similar for understanding of math concepts. Attending a center program is associated with a 1.2 point $(0.12$ $S D)$ increase in math performance. The estimates for the social-behavioral index show negative effects from exposure to center programs. Center attendance is associated with a 0.089 (SD) point decrease in the behavior index.

The effects associated with attending a Head Start preschool for the full sample are not statistically different from zero for either pre-reading or math skills, although they do suggest a negative effect on social behavior of $0.12 S D$ units below children who remain in parental care. One caution about the Head Start effects is that of omitted variable bias. Because the negative Head Start effects drop significantly as additional controls are included in the model, we may have not fully accounted for selection effects and that additional controls are needed.

Many studies have postulated that the effects of center programs will differ across diverse groups of families. For example, children in households with many resources for advancing early language, pre-reading, and math skills may not benefit as much from center care as those in families without such resources. To examine whether child care choices have differing impacts by family income, we also estimated our model for children from families in the lowest incometo-needs ratio quartile, the middle half and the top quartile. We see no statistically significant difference across these three income groups. With few exceptions, center programs appear to 
advance pre-reading and math concepts while under cutting social behavior. The magnitudes of the point estimates do vary, with children from middle-income homes experiencing the biggest gains in pre-reading skills. However, the relative magnitudes of the effects for low income children are sensitive to the definition of low-income. With a more restrictive definition of poverty, i.e. an income-to-needs ratio of less than 0.5 or very low parental education, we find that the poorest children do enjoy the greatest academic returns from center programs.

We employed both instrumental variables and propensity score matching to test the model specification. Table 3 shows that our instruments were not strong enough to accurately estimate child care effects: while the point estimates are larger, so are the standard errors. However, the statistical matching results are quite similar to those discussed above. Center attendance is associated with a $0.13 S D$ increase in pre-reading and math performance and, again, a decrease in the social-behavior index. We also ran the model for each of the three income groups using weights from propensity-score matching. The results are very similar to the OLS results, indicating that the limited overlap across child care types is unlikely to be biasing our results. One minor difference is that the results are slightly different for pre-reading among children in the high-income group, along with the middle-income behavior relative to social behavior, but this is solely due to differences between parental and other non-parental care. Parental care is the comparison group for the OLS results, while the combination of parental and non-parental care is the comparison for the statistical matching results. The propensity score estimates consistently produce smaller standard errors than the OLS estimates, strengthening our confidence in the results.

In Table 4 we present results separately for White, Black and Hispanic children. While the estimates are similar in direction to the results presented above for the entire sample, the magnitude of academic gains are dramatically larger for English-proficient Hispanic students. For instance, center care is associated with a $0.23 S D$ increase in the reading scores of Hispanic students, almost three times the effect size for White children. This effect size is quite similar to the learning gains observed after Tennessee lowered class sizes to 15-18 students in kindergarten and the early grades. At the same time, center programs do not have a significantly negative impact on the social behavior of Hispanic children. In addition, Hispanic children who attend Head Start do better in reading than those who receive maternal care, though the Head Start effect is smaller then the center effect. 
Next we move to the effects associated with the duration and intensity with which children are exposed to center programs. Table 5 gives the results of the duration measure. Column 1 shows that for the full sample, the greatest benefit of center care for reading and math skills accrues to children who start center-based programs between the ages of two and three. Interestingly, those who start both before and after that time appear to gain less. Except for those who entered after age five, attending a center remains associated with higher scores than parental care. The results for social behavior are different, although perhaps predictable. The negative behavioral effects are greater the earlier a child enters.

These estimations aim to gauge causal effects from exposure to center programs. However, it is possible that we have not controlled for some factor that affects both the age of entry and child development (despite the rich set of controls applied). But, the difference in the relationship between duration and achievement in comparison to duration and behavior suggests that the results are not driven solely by a simple story of selection bias. If particularly strong families put their kids in center care at a given age and we were not able to adjust for that with the many controls, we would expect to see the highest scores across all three measures for children associated with the duration of center attendance. This is not the case. The socialbehavioral effects differ from the cognitive effects.

The middle three columns of Table 5 give the results separately for the lowest quartile, middle half and highest quartile of families' income-to-needs ratio. Again the results are similar across the income groups. Almost uniformly, the strongest reading and math effects occur for those who enter centers between the ages of two and three, and the worst behavioral effects occur for those who enter the earliest. With only a few exceptions, the pattern that is evident across income groups also holds for Whites, Blacks and Hispanics. (These results are available from the authors). One notable exception is that starting a center program early does not seem to have any negative impact on English-proficient Hispanic children in the sample.

As well as duration, children differ meaningfully in how much time they spend in center care during a given year. Table 6 shows the effect of intensity of care using dummy variables to capture whether a child attended a center for 15-30 hours per week or for more than 30 hours per week, for at least nine months per year. In this case, the coefficient on the center care dummy variable picks up the effect of any center attendance and should be added to the coefficients on the measures of intensity to get the total effect of intense attendance relative to parental care. 
The first column presents the results for the full sample. These estimates suggest that intensity - attending at least 15 hours per week - substantially increases the contribution of center programs to cognitive growth. Attending for more than 30 hours a week is also associated with positive cognitive skills. Consistent with previous research, we find longer hours are associated with negative behavioral outcomes. Not only do the negative behavioral effects appear for those with at least 15 hours of care per week, but additional care, as measured by at least 30 hours of center care, more than doubles this negative effect, from an effect size of -0.10 $S D$ to $-0.25 S D$ for the full sample. For children from middle-class and affluent families these decrements are -0.28 SD and -0.29 SD. This approximates about two-thirds the suppressing effect experienced by children who grow-up with a moderately depressed mother.

The estimates for the full sample obscure important differences across income groups, as shown in the middle panel of Table 6. For the low-income group, only children who attend a center program for more than 30 hours experience significant gains in pre-reading skills. This same group experiences no negative social-behavioral effects from additional hours in a center. At the other extreme, children from higher-income families do not show any significant gains from attending centers for more than 30 hours per week and, in sharp contrast to the low-income children, those from higher income families display increasingly negative behavior the longer they attend a center program each week.

The impact of intensive exposure to a center program also varies dramatically based on the child's race, as shown in the righthand panel of Table 6. For example, White children who attend a center program for 15 to 30 hours a week for at least nine months a year show higher cognitive gains than children who have more limited exposure. In contrast, Hispanic children do not seem to gain from extra hours; in fact, more intensive exposure is associated at times with a drop in pre-reading and math performance. The results for Black children are more mixed: high intensity attendance is associated with increased pre-reading scores, but not math performance. For behavior, intense exposure to a center has a negatively association for White children, but interestingly has no discernible effect for Black or Hispanic children. It's important to remember that our results for Hispanic children are only generalizable for those with minimal English 
proficiency; further research would be useful in assessing whether these effects also hold for Hispanic children with more limited English. ${ }^{9}$

In addition, while the models presented combine months with hours, we also ran specifications with these separated. Table 7 shows that additional hours hold a positive effect on cognitive outcomes when they are combined with extended months in centers. Moreover, additional months do not appear to have a detrimental affect on behavior, instead it is the long hours of attendance each week that appears to drive the decrements in social behavior.

\section{Conclusion}

This study began with the question: How much might be too much when it comes to children's attendance at preschool centers? Our findings using the ECLS-K show that the answer depends upon which child and which domain of child development is being examined. We found that, on average, exposure to a center program prior to starting kindergarten is associated with about a $0.1 S D$ difference in pre-reading and math skills on average, though it is also associated with approximately the same size negative effect on a teacher-reported behavioral measure that captures approaches to learning, self-control and a variety of interpersonal skills. These differential effects suggest further exploration of the characteristics of center attendance that affect cognitive and social outcomes. Is there a type of center care that maximizes the positive cognitive effects while minimizing the negative social effects? In this paper we have looked at the amount of center care, both duration and intensity, that children experience.

Are there optimal ages for children to enter center programs, or amounts of exposure that are better, in order to maximize the positive cognitive effects while minimizing negative social effects? We found consistent effects for the duration of center attendance across income groups. The strongest cognitive benefits were enjoyed by youngsters who entered a center program between the ages of two and three years of age. Children who started earlier did not display greater pre-reading or math skills, and, in fact, the predicted averages are somewhat lower than for those who started between the ages of two and three years-old.

\footnotetext{
${ }^{9}$ We chose the categories of hours in Tables 6 and 7 to correspond with half-day and full-day center-based programs; however, there are numerous ways of categorizing intensity. From examination of the distribution of hours of care for children who used center programs, there are two peaks at approximately 10 hours and 40 hours. Based on this distribution, we re-ran the model with alternative classifications (for example, less than 20 hours, 20 to 40 hours, and greater than 40 hours) and obtained very similar estimates to those reported in Tables 6 and 7.
} 
In addition, the negative behavioral effects associated with center attendance, compared with parental care, are much greater for those who enter a center at less than two years of age and are particularly large for those who start at less than one year of age. For both low and high income children, starting a center program before the age of two is not particularly beneficial for cognitive development and appears to be detrimental for social development. One caveat to these findings is that the ECLS data only provide information on when the child started a center, not a complete child-care history; so, start date serves as a proxy for duration in our analysis.

Our results for the intensity of attending a center program, measured in hours per week and months per year, do vary across family income groups. ${ }^{10}$ For children from low-income families, additional hours per week are associated with some gains in reading and math and few detrimental effects on social development. But while high income children enjoy gains in prereading and math skills when attending at moderate levels (15 to 30 hours per week), they see no cognitive gains and substantially greater behavioral problems associated with additional hours of weekly center attendance. The study also highlights variation in effects for children of different races. English-proficient Hispanic children seem to benefit more in terms of cognitive development from center attendance than White or Black children with similar characteristics, and Hispanic children's center exposure is not associated with lower rates of social-behavioral growth.

Assessing the cost-benefit of universal preschool or other center-based programs is well beyond the scope of this report. Yet we do find that exposure to at least a half-day center program yields cognitive benefits for most children. The good news is that middle-class children appear to benefit cognitively. The bad news is that universal access may not dramatically close early learning gaps. Our findings also suggest that greater benefits can accrue from interventions that start earlier than age four. Generally, children learn more when they start center care between two and three years of age. In addition, while half day programs may be beneficial for children from higher income families, full day programs better serve children from lower income families, allowing them to gain pre-reading and math skills without detriment to social behavior.

\footnotetext{
${ }^{10}$ Note that this analysis assesses the effects of hours of attendance within a center program, not total hours of nonparental care. In estimates not presented in this paper, we did not find a statistically significant relationship between total hours of child care, of all types, and child outcomes.
} 


\section{References}

August, D. \& Hakuta, K., Eds. (1997). Improving Schooling for Language Minority Children: A Research Agenda. Washington, D.C.: National Academy Press.

Barnett, S. (1995). Long-term effects of early childhood programs on cognitive and school outcomes. The Future of Children, 5, 25-50.

Bates, J. E., Marvinney, D., Kelly, T., Dodge, K. A., Bennett, D. S., \& Pettit, G. S. (1994). Child care history and kindergarten adjustment. Developmental Psychology, 30, 690-700.

Belsky, J. (2001). Developmental risks (still) associated with early child care. Journal of Child Psychology \& Psychiatry \& Allied Disciplines, 42, 845-859.

Belsky, J. (2002). Quantity Counts: Amount of Child Care and Children's Social-Emotional Development. Developmental and Behavioral Pediatrics, 23, 167-170.

Blank, H., Schulman, K., \& Ewan, D. (1999). Seeds of Success. Washington, D.C.: Children's Defense Fund. http://www.childrensdefense.org/pdf/seeds_of_success.pdf.

Burchinal, M. R., Campbell, F. A., Bryant, D. B., Wasik, B. H., Ramey, C. T. (1997). Early intervention and mediating processes in cognitive performance of children of low-income African-American families. Child Development, 68 (5), 935-954.

Bridges, M., Fuller, B. C., Rumberger, R., \& Tran, L. (2004). Preschool for California's children: Promising benefits, unequal access. PACE Policy Brief, 04-3, Berkeley, CA: Policy Analysis for California Education (PACE).

Campbell, F.A. \& Ramey, C.T. (1994). Effects of early intervention on intellectual and academic achievement: A follow-up study of children from low-income families. Child Development 65, 684-698.

Campbell, F. A., \& Ramey, C. T. (1995). Cognitive and school outcomes for high-risk AfricanAmerican student at middle adolescence: Positive effects of early intervention. American Educational Research Journal, 32, 743-772.

Campbell, F. A., Ramey, C. T. Pungello, E. P., Miller-Johnson, S., \& Sparling, J. J. (2002). Early childhood education: Young adult outcomes from the Abecedarian Project. Applied Developmental Science, 6 (1), 42-57.

Clements, M., Reynolds, A., \& Hickey, E. (2004). Site-level Predictors of School and Social Competence in the Chicago Child-Parent Centers. Early Childhood Research Quarterly, 19, 273-296.

Colwell, M. J., Pettit, G. S., Meece, D., Bates, J. E., Dodge, K. A. (2001). Cumulative Risk and Continuity in Nonparental Care from Infancy to Early Adolescence. Merrill-Palmer Quarterly, 47, 207-234.

Early Childhood Longitudinal Study, Kindergarten Class of 1998-99. ECLS-K Base Year Data Files and Electronic Code Book. On the Web, National Center for Educational Statistics.

Fryer, R. \& Levitt, S (2004). "Understanding the Black-White Test Score Gap in the First Two Years of School," The Review of Economics and Statistics, May.

Fuller, B., Loeb,S., Strath, A. and Carrol, A.B. (2004). "States Formation of the Child Care Sector: Family Demand and Central Policy," Sociology of Education 77, 337-358.

Fuller, B. C., Livas, A., \& Bridges, M. (2005). How to expand and improve preschool in California: Ideals, evidence, and policy options. PACE Working Paper 05-1. Berkeley, California: Policy Analysis for California Education (PACE).

Garces, E., Thomas, D., \& Currie, J. (2002). Longer term effects of Head Start. The American Economic Review, 92, 999-1012. 
Han, Wen-Jui, Jane Waldfogel and Jeanne Brooks-Gunn. 2001. "The Effects of Early Maternal Employment on Later Cognitive and Behavioral Outcomes." Journal of Marriage and Family 63, February, pp. 336-354.

Heckman, J., Ichimura, H. \& Todd, P. (1998), 'Matching as an econometric evaluation estimator', Review of Economic Studies 65, 261-294.

Hofferth, S., Shauman, K., Henke, R., \& West, J. (1995). Characteristics of Children's Early Care and Education Programs: Data from the 1995 National Household Education Survey. Washington, D.C.: National Center for Education Statistics.

Liang, X., Fuller, B., \& Singer, J. (2000). Ethnic differences in child care selection: The influence of family structure, parenting practices, and home language. Early Childhood Research Quarterly, 15, 357-384.

Loeb, S., Fuller, B., Kagan, S. L., \& Carrol, B. (2004). Child care in poor communities: Early learning effects of type, quality, and stability. Child Development, 75, 47-65.

Magnuson, K. A., Ruhm, C. J., \& Waldfogel, J. (2004). Does pre-kindergarten improve school preparation and performance? National Bureau of Economic Research Working Paper 10452. Cambridge, MA: NBER.

Magnuson, K.A., Meyers, M, Ruhm, C.J., and Waldfogel, J. (2004). "Inequality in Preschool Education and School Readiness." American Educational Research Journal 41: 115-157.

NICHD ECCRN \& Duncan, G. (2003). Modeling the Impacts of Child Care Quality on Childrens Preschool Cognitive Development. Child Development, 74, 1454-1475.

NICHD ECCRN. (2002). Maternal employment and child cognitive outcomes in the first 3 years of Life: The NICHD Study of Early Child Care. Child Development, 73, 1052-1072.

NICHD ECCRN. (2003). Does the amount of time spent in child care predict socioemotional adjustment during the transition to kindergarten? Child Development, 74, 976-1005.

O’Brien-Strain, M., Moye, L., \& Sonenstein, F. L. (2003). Arranging and Paying for Child Care. San Francisco, California: Public Policy Institute of California.

Reardon, S. (2003). Sources of educational inequality: The growth of racial/ethnic and socioeconomic test score gaps in kindergarten and first grade. State College, PA: Penn State University (Manuscript).

Reynolds, A. J., \& Temple, J. A. (1998). Extended early childhood intervention and school achievement: Age 13 findings from the Chicago Longitudinal Study. Child Development, 69, 231-246.

Rumberger, R. W., \& Arellano, B. (2003). Understanding and Addressing the Latino Achievement Gap in California. Draft Report submitted to the Latino Policy Institute, California Policy Research Center, University of California.

Schulman, K., \& Blank, H. (2004). Child Care Assistance Policies 2001-2004: Families Struggling to Move Forward, States Going Backward. Washington, D.C.: National Women's Law Center. http://www.nwlc.org/pdf/childcaresubsidyfinalreport.pdf

Shonkoff, J. P. \& Phillips, D. A., Eds. (2000). From Neurons to Neighborhoods: The Science of Early Child Development. Washington, D.C.: National Academy Press.

Smith, T., Kleiner, A., Parsad, B., Farris, E., \& Green, B. (2003). Prekindergarten in the U.S. Public Schools. Washington, DC: U. S. Department of Education.

Snow, C. E., Burns, M. S., \& Griffin, P. (Eds.). (1998). Preventing Reading Difficulties in Young Children. Washington, DC: National Academy Press.

Vandell, D. L. \& Ramanan, J. (1992). Effects of Early and Recent Maternal Employment on Children from Low-Income Families. Child Development, 63, 938-949. 
Table 1: Descriptives of Selected Variables by Child Care Type

\begin{tabular}{|c|c|c|c|c|c|}
\hline & All & Parental & Center & Head Start & Other \\
\hline Sample Size & 14162 & 2363 & 9015 & 1093 & 1691 \\
\hline South & 0.37 & 0.38 & 0.36 & 0.44 & 0.34 \\
\hline Birth Weight & $118(21)$ & $118(22)$ & $119(21)$ & $114(23)$ & $117(21)$ \\
\hline Race/Ethnicity & 0.16 & 0.12 & 0.14 & 0.39 & 0.13 \\
\hline Hispanic & 0.13 & 0.17 & 0.11 & 0.19 & 0.18 \\
\hline English Only at Home & 0.84 & 0.80 & 0.86 & 0.80 & 0.81 \\
\hline Single parent family & 0.22 & 0.16 & 0.20 & 0.43 & 0.28 \\
\hline Mother's Education & 0.10 & 0.19 & 0.06 & 0.24 & 0.12 \\
\hline HS & 0.31 & 0.36 & 0.27 & 0.44 & 0.37 \\
\hline Vocational & 0.06 & 0.06 & 0.05 & 0.06 & 0.06 \\
\hline BA & 0.16 & 0.10 & 0.20 & 0.02 & 0.10 \\
\hline Some Grad & 0.02 & 0.01 & 0.02 & 0.01 & 0.01 \\
\hline MA & 0.05 & 0.02 & 0.06 & 0.00 & 0.03 \\
\hline PhD & 0.01 & 0.00 & 0.02 & 0.00 & 0.01 \\
\hline Mother Employed Full Time & 0.46 & 0.24 & 0.48 & 0.44 & 0.65 \\
\hline Father Employed Full Time & 0.70 & 0.73 & 0.74 & 0.44 & 0.67 \\
\hline WIC Participation & 0.45 & 0.49 & 0.37 & 0.89 & 0.52 \\
\hline Income to Needs & 0.07 & 0.08 & 0.04 & 0.22 & 0.06 \\
\hline $.5-1.0$ & 0.11 & 0.14 & 0.08 & 0.29 & 0.13 \\
\hline Home: \# of children's books & $78(59)$ & $72(58)$ & $85(60)$ & $49(48)$ & $69(56)$ \\
\hline tv hours & $1.84(1.20)$ & $1.96(1.25)$ & $1.73(1.12)$ & $2.22(1.42)$ & $1.98(1.28)$ \\
\hline visited library & 0.55 & 0.53 & 0.57 & 0.46 & 0.49 \\
\hline spanked & 0.20 & 0.22 & 0.18 & 0.27 & 0.23 \\
\hline Parent at School: & & & & & \\
\hline PTA meeting & 0.34 & 0.36 & 0.35 & 0.30 & 0.27 \\
\hline Parent-Tchr conference & 0.86 & 0.83 & 0.88 & 0.79 & 0.84 \\
\hline Volunteered & 0.50 & 0.50 & 0.55 & 0.31 & 0.42 \\
\hline
\end{tabular}


Table 2: OLS Estimates of the Effects of Child Care Settings on Cognitive and Behavioral Outcomes by Income (Full population, Lowest quartile, middle half and upper quartile)

\begin{tabular}{|c|c|c|c|c|c|}
\hline & All & Low & Middle & High & Very Low \\
\hline & \multicolumn{5}{|c|}{ Reading } \\
\hline \multirow[t]{2}{*}{ Center Care } & $1.116^{* * *}$ & 0.620 & $1.272 * * *$ & 0.806 & $2.015 * * *$ \\
\hline & $(0.224)$ & $(0.432)$ & $(0.304)$ & $(0.586)$ & $(0.770)$ \\
\hline \multirow[t]{2}{*}{ Head Start Care } & -0.413 & -0.821 & 0.120 & --- & 0.367 \\
\hline & $(0.351)$ & $(0.504)$ & $(0.589)$ & --- & $(0.848)$ \\
\hline \multirow[t]{2}{*}{ Other Non-Parent } & -0.414 & -0.316 & -0.280 & -0.882 & -0.970 \\
\hline & $(0.300)$ & $(0.585)$ & $(0.407)$ & $(0.765)$ & $(1.169)$ \\
\hline Observations & 11577 & 2670 & 5891 & 3016 & 829 \\
\hline \multirow[t]{2}{*}{ R-squared } & 0.36 & 0.28 & 0.30 & 0.33 & .32 \\
\hline & \multicolumn{5}{|c|}{ Math } \\
\hline \multirow[t]{2}{*}{ Center Care } & $1.196 * * *$ & $1.188^{* * * *}$ & $1.182 * * *$ & $1.011 *$ & $2.191 * * *$ \\
\hline & $(0.215)$ & $(0.442)$ & $(0.289)$ & $(0.544)$ & $(0.799)$ \\
\hline \multirow[t]{2}{*}{ Head Start Care } & 0.322 & 0.514 & 0.097 & --- & 1.138 \\
\hline & $(0.336)$ & $(0.515)$ & $(0.560)$ & --- & $(0.880)$ \\
\hline \multirow[t]{2}{*}{ Other Non-Parent } & 0.174 & 0.231 & 0.410 & -0.495 & 0.045 \\
\hline & $(0.288)$ & $(0.598)$ & $(0.387)$ & $(0.710)$ & $(1.213)$ \\
\hline Observations & 11577 & 2670 & 5891 & 3016 & 829 \\
\hline \multirow[t]{2}{*}{ R-squared } & 0.37 & 0.29 & 0.30 & 0.32 & .31 \\
\hline & \multicolumn{5}{|c|}{ Behavior } \\
\hline \multirow[t]{2}{*}{ Center Care } & $-0.089 * * *$ & $-0.158 * * *$ & -0.014 & $-0.176 * *$ & $-0.238 * *$ \\
\hline & $(0.026)$ & $(0.054)$ & $(0.035)$ & $(0.068)$ & $(0.096)$ \\
\hline \multirow[t]{2}{*}{ Head Start Care } & $-0.122 * * *$ & -0.103 & $-0.141 * *$ & --- & -0.158 \\
\hline & $(0.041)$ & $(0.062)$ & $(0.067)$ & --- & $(0.105)$ \\
\hline \multirow[t]{2}{*}{ Other Non-Parent } & $0.105^{* * *}$ & -0.027 & $0.166^{* * *}$ & 0.080 & -0.224 \\
\hline & $(0.035)$ & $(0.072)$ & $(0.047)$ & $(0.089)$ & $(0.145)$ \\
\hline Observations & 11577 & 2670 & 5891 & 3016 & 829 \\
\hline $\mathrm{R}$-squared & 0.14 & 0.18 & 0.14 & 0.15 & .27 \\
\hline
\end{tabular}

Standard errors in parentheses. $*$ significant at $10 \% ; * *$ significant at $5 \%$; *** significant at $1 \%$ 
Table 3: Specification Checks of the Effects of Child-Care Type on Children's Cognitive and Social Outcomes

\begin{tabular}{|c|c|c|c|}
\hline & \multicolumn{3}{|c|}{ Instrumental Variables Results } \\
\hline & Reading & Math & Behavior \\
\hline \multirow[t]{2}{*}{ Center Care } & $11.001 * *$ & $8.893^{*}$ & -0.724 \\
\hline & $(5.191)$ & $(4.792)$ & $(0.570)$ \\
\hline \multirow[t]{2}{*}{ Head Start Care } & -1.388 & -0.702 & $-1.417 * *$ \\
\hline & $(6.374)$ & $(5.883)$ & $(0.700)$ \\
\hline \multirow{2}{*}{ Other Non-Parent Care } & 6.714 & 5.693 & -0.476 \\
\hline & $(4.265)$ & $(3.936)$ & $(0.468)$ \\
\hline \multirow[t]{4}{*}{ R-squared $(n=9490)$} & 0.21 & 0.27 & 0.04 \\
\hline & \multicolumn{3}{|c|}{ Statistical Matching Results } \\
\hline & \multicolumn{3}{|c|}{ Head Start Children Excluded } \\
\hline & Reading & Math & Behavior \\
\hline \multirow[t]{2}{*}{ Center Care $(n=10763)$} & $1.289 * * *$ & $1.255^{* * *}$ & $-0.134 * * *$ \\
\hline & $(0.157)$ & $(0.148)$ & $(0.018)$ \\
\hline \multirow[t]{3}{*}{ R-squared } & 0.34 & 0.34 & 0.13 \\
\hline & \multicolumn{3}{|c|}{ Center Care Children Excluded } \\
\hline & Reading & Math & Behavior \\
\hline \multirow[t]{2}{*}{ Head Start $(n=3992)$} & $-.453^{*}$ & 0.257 & $-0.155 * * *$ \\
\hline & $(0.234)$ & $(0.234)$ & $(0.029)$ \\
\hline R-squared & 0.34 & 0.34 & 0.13 \\
\hline
\end{tabular}

Models include all child/family controls and zip controls as well as dummy variables for Head Start participation and other non-parental care. Standard errors in parentheses. * significant at $10 \%$; ** significant at $5 \%$; *** significant at $1 \%$ 
Table 4: OLS Estimates of the Effects of Child-Care Settings on Cognitive and Behavioral Outcomes, by RACE

\begin{tabular}{|c|c|c|c|c|}
\hline & $A L L$ & White & Black & Hispanic \\
\hline \multirow{3}{*}{ Center Care } & \multicolumn{4}{|c|}{ Reading } \\
\hline & $1.116 * * *$ & $0.852 * * *$ & 1.026 & $2.289 * * *$ \\
\hline & $(0.224)$ & $(0.276)$ & $(0.694)$ & $(0.653)$ \\
\hline \multirow[t]{2}{*}{ Head Start Care } & -0.413 & -0.491 & -1.175 & $1.553 *$ \\
\hline & $(0.351)$ & $(0.546)$ & $(0.806)$ & $(0.884)$ \\
\hline \multirow[t]{2}{*}{ Other Non-Parent Care } & -0.414 & -0.553 & -0.687 & 1.195 \\
\hline & $(0.300)$ & $(0.377)$ & $(0.918)$ & $(0.828)$ \\
\hline Observations & 11577 & 7495 & 1549 & 1456 \\
\hline \multirow{2}{*}{ R-squared } & 0.36 & 0.33 & 0.39 & 0.39 \\
\hline & \multicolumn{4}{|c|}{ Math } \\
\hline \multirow[t]{2}{*}{ Center Care } & $1.196 * * *$ & $1.043 * * *$ & $1.602 * *$ & $1.996 * * *$ \\
\hline & $(0.215)$ & $(0.269)$ & $(0.645)$ & $(0.603)$ \\
\hline \multirow[t]{2}{*}{ Head Start Care } & 0.322 & 0.703 & 0.173 & 0.974 \\
\hline & $(0.336)$ & $(0.532)$ & $(0.750)$ & $(0.816)$ \\
\hline \multirow{2}{*}{ Other Non-Parent Care } & 0.174 & 0.067 & -0.133 & $1.302 *$ \\
\hline & $(0.288)$ & $(0.368)$ & $(0.854)$ & $(0.764)$ \\
\hline Observations & 11577 & 7495 & 1549 & 1456 \\
\hline \multirow[t]{2}{*}{ R-squared } & 0.37 & 0.33 & 0.37 & 0.37 \\
\hline & \multicolumn{4}{|c|}{ Behavior } \\
\hline \multirow[t]{2}{*}{ Center Care } & $-0.089 * * *$ & $-0.072 * *$ & $-0.257 * * *$ & -0.081 \\
\hline & $(0.026)$ & $(0.032)$ & $(0.088)$ & $(0.070)$ \\
\hline \multirow[t]{2}{*}{ Head Start Care } & $-0.122 * * *$ & $-0.241 * * *$ & $-0.216 * *$ & 0.028 \\
\hline & $(0.041)$ & $(0.064)$ & $(0.102)$ & $(0.094)$ \\
\hline \multirow{2}{*}{ Other Non-Parent Care } & $0.105 * * *$ & $0.119 * * *$ & -0.062 & 0.132 \\
\hline & $(0.035)$ & $(0.044)$ & $(0.116)$ & $(0.088)$ \\
\hline Observations & 11577 & 7495 & 1549 & 1456 \\
\hline R-squared & 0.14 & 0.15 & 0.18 & 0.23 \\
\hline
\end{tabular}

Standard errors in parentheses. * significant at $10 \%$; ** significant at $5 \%$; *** significant at $1 \%$ 
Table 5: OLS Estimates of the Effects of Age at Center Entry on Cognitive and Social Outcomes By Income Group

\begin{tabular}{|c|c|c|c|c|}
\hline & $\begin{array}{c}\text { All } \\
(11577)\end{array}$ & $\begin{array}{l}\text { Low } \\
(2670)\end{array}$ & $\begin{array}{l}\text { Middle } \\
(5891)\end{array}$ & $\begin{array}{c}\text { High } \\
(3061)\end{array}$ \\
\hline & \multicolumn{4}{|c|}{ Reading } \\
\hline Started Center Age 0-1 & $\begin{array}{l}0.999 * * * \\
(0.374)\end{array}$ & $\begin{array}{l}0.473 \\
(0.965)\end{array}$ & $\begin{array}{l}1.351^{* *} \\
(0.534)\end{array}$ & $\begin{array}{l}0.242 \\
(0.752)\end{array}$ \\
\hline Started Center Age 1-2 & $\begin{array}{l}1.306 * * * \\
(0.415)\end{array}$ & $\begin{array}{l}1.161 \\
(1.023)\end{array}$ & $\begin{array}{l}1.171 * * \\
(0.589)\end{array}$ & $\begin{array}{l}0.552 \\
(0.820)\end{array}$ \\
\hline Started Center Age 2-3 & $\begin{array}{l}1.952 * * * \\
(0.328)\end{array}$ & $\begin{array}{l}2.111 * * * \\
(0.799)\end{array}$ & $\begin{array}{l}1.944 * * * \\
(0.485)\end{array}$ & $\begin{array}{l}1.338^{* *} \\
(0.669)\end{array}$ \\
\hline Started Center Age 3-4 & $\begin{array}{l}1.324 * * * \\
(0.260)\end{array}$ & $\begin{array}{l}-0.009 \\
(0.555)\end{array}$ & $\begin{array}{l}1.700 * * * \\
(0.359)\end{array}$ & $\begin{array}{l}1.001 \\
(0.619)\end{array}$ \\
\hline Started Center Age 4-5 & $\begin{array}{l}0.728 * * * \\
(0.260)\end{array}$ & $\begin{array}{l}0.710 \\
(0.509)\end{array}$ & $\begin{array}{l}0.776 * * \\
(0.351)\end{array}$ & $\begin{array}{l}0.296 \\
(0.681)\end{array}$ \\
\hline Started Center Age $>5$ & $\begin{array}{l}0.475 \\
(0.557)\end{array}$ & $\begin{array}{l}0.244 \\
(1.164)\end{array}$ & $\begin{array}{l}0.814 \\
(0.737)\end{array}$ & $\begin{array}{l}-0.370 \\
(1.323)\end{array}$ \\
\hline \multirow[t]{2}{*}{ R-Squared } & 0.36 & 0.28 & 0.30 & 0.33 \\
\hline & \multicolumn{4}{|c|}{ Math } \\
\hline Started Center Age 0-1 & $\begin{array}{l}1.404 * * * \\
(0.359)\end{array}$ & $\begin{array}{l}0.303 \\
(0.986)\end{array}$ & $\begin{array}{l}1.590 * * * \\
(0.508)\end{array}$ & $\begin{array}{l}1.214 * \\
(0.697)\end{array}$ \\
\hline Started Center Age 1-2 & $\begin{array}{l}1.103^{* * * *} \\
(0.398)\end{array}$ & $\begin{array}{l}1.537 \\
(1.046)\end{array}$ & $\begin{array}{l}1.010^{*} \\
(0.560)\end{array}$ & $\begin{array}{l}0.471 \\
(0.761)\end{array}$ \\
\hline Started Center Age 2-3 & $\begin{array}{l}1.783^{* * * *} \\
(0.315)\end{array}$ & $\begin{array}{l}2.731 * * * \\
(0.817)\end{array}$ & $\begin{array}{l}1.658 * * * \\
(0.461)\end{array}$ & $\begin{array}{l}1.285^{* *} \\
(0.621)\end{array}$ \\
\hline Started Center Age 3-4 & $\begin{array}{l}1.393^{* * *} \\
(0.250)\end{array}$ & $\begin{array}{l}1.126^{* *} \\
(0.567)\end{array}$ & $\begin{array}{l}1.357 * * * \\
(0.341)\end{array}$ & $\begin{array}{l}1.379 * * \\
(0.574)\end{array}$ \\
\hline Started Center Age 4-5 & $\begin{array}{l}0.851 * * * \\
(0.250)\end{array}$ & $\begin{array}{l}1.087 * * \\
(0.520)\end{array}$ & $\begin{array}{l}0.889 \text { *** } \\
(0.334)\end{array}$ & $\begin{array}{l}0.157 \\
(0.632)\end{array}$ \\
\hline Started Center Age $>5$ & $\begin{array}{l}0.837 \\
(0.534)\end{array}$ & $\begin{array}{l}0.280 \\
(1.189)\end{array}$ & $\begin{array}{l}1.005 \\
(0.701)\end{array}$ & $\begin{array}{l}0.700 \\
(1.227)\end{array}$ \\
\hline \multirow[t]{2}{*}{ R-Squared } & 0.37 & 0.29 & 0.30 & 0.32 \\
\hline & \multicolumn{4}{|c|}{ Behavior } \\
\hline Started Center Age 0-1 & $\begin{array}{l}-0.287 * * * \\
(0.044)\end{array}$ & $\begin{array}{l}-0.372 * * * \\
(0.119)\end{array}$ & $\begin{array}{l}-0.159 * * * \\
(0.061)\end{array}$ & $\begin{array}{l}-0.388^{* * * *} \\
(0.087)\end{array}$ \\
\hline Started Center Age 1-2 & $\begin{array}{l}-0.209 * * * \\
(0.048)\end{array}$ & $\begin{array}{l}-0.203 \\
(0.127)\end{array}$ & $\begin{array}{l}-0.157^{* *} \\
(0.067)\end{array}$ & $\begin{array}{l}-0.303^{* * *} \\
(0.095)\end{array}$ \\
\hline Started Center Age 2-3 & $\begin{array}{l}-0.157 * * * \\
(0.038)\end{array}$ & $\begin{array}{l}-0.267 * * * \\
(0.099)\end{array}$ & $\begin{array}{l}-0.068 \\
(0.055)\end{array}$ & $\begin{array}{l}-0.233^{* * *} \\
(0.078)\end{array}$ \\
\hline Started Center Age 3-4 & $\begin{array}{l}-0.085^{* * * *} \\
(0.030)\end{array}$ & $\begin{array}{l}-0.154 * * \\
(0.069)\end{array}$ & $\begin{array}{l}-0.011 \\
(0.041)\end{array}$ & $\begin{array}{l}-0.157 * * \\
(0.072)\end{array}$ \\
\hline Started Center Age 4-5 & $\begin{array}{l}-0.026 \\
(0.030)\end{array}$ & $\begin{array}{l}-0.105^{*} \\
(0.063)\end{array}$ & $\begin{array}{l}0.040 \\
(0.040)\end{array}$ & $\begin{array}{l}-0.073 \\
(0.079)\end{array}$ \\
\hline Started Center Age $>5$ & $\begin{array}{l}-0.059 \\
(0.065)\end{array}$ & $\begin{array}{l}-0.159 \\
(0.144)\end{array}$ & $\begin{array}{l}-0.012 \\
(0.084)\end{array}$ & $\begin{array}{l}-0.056 \\
(0.154)\end{array}$ \\
\hline R-Squared & 0.14 & 0.18 & 0.15 & 0.16 \\
\hline
\end{tabular}

Models include all child/family controls, zip controls and state fixed effects, as well as dummy variables for Head Start participation, other non-parental care, and unknown center start date. Standard errors are in parentheses.

* significant at $10 \%$; ** significant at $5 \%$; *** significant at $1 \%$. 
Table 6: OLS Estimates of the Effects of Intensity of Exposure to Center Programs on Cognitive and Social-Behavioral Outcomes by Income and Race

\begin{tabular}{|c|c|c|c|c|c|c|c|}
\hline & $\begin{array}{c}\text { All } \\
(11558)\end{array}$ & $\begin{array}{c}\text { Low } \\
(2665) \\
\end{array}$ & $\begin{array}{c}\text { Middle } \\
(5882)\end{array}$ & $\begin{array}{c}\text { High } \\
(3011)\end{array}$ & $\begin{array}{l}\text { White } \\
(7482) \\
\end{array}$ & $\begin{array}{c}\text { Black } \\
(1548) \\
\end{array}$ & $\begin{array}{c}\text { Hispanic } \\
(1452)\end{array}$ \\
\hline \multicolumn{8}{|l|}{ Reading: } \\
\hline Center Care & $\begin{array}{c}0.818 * * * \\
(0.237)\end{array}$ & $\begin{array}{c}0.272 \\
(0.475)\end{array}$ & $\begin{array}{c}0.935 * * * \\
(0.321)\end{array}$ & $\begin{array}{c}0.674 \\
(0.605)\end{array}$ & $\begin{array}{c}0.617 * * \\
(0.288)\end{array}$ & $\begin{array}{c}0.295 \\
(0.758)\end{array}$ & $\begin{array}{c}2.450 * * * \\
(0.728)\end{array}$ \\
\hline 15-30 hours/week, 9 months & $\begin{array}{c}0.807 * * * \\
(0.261)\end{array}$ & $\begin{array}{c}0.188 \\
(0.659)\end{array}$ & $\begin{array}{c}0.620 \\
(0.390)\end{array}$ & $\begin{array}{c}0.977 * * \\
(0.433)\end{array}$ & $\begin{array}{c}1.157 * * * \\
(0.309)\end{array}$ & $\begin{array}{c}0.205 \\
(0.939)\end{array}$ & $\begin{array}{l}-1.629 * \\
(0.849)\end{array}$ \\
\hline $\begin{array}{l}\text { At least } 30 \text { hours/week, } 9 \text { months } \\
\text { R-squared }\end{array}$ & $\begin{array}{c}0.854 * * * \\
(0.241) \\
0.36 \\
\end{array}$ & $\begin{array}{c}1.495 * * * \\
(0.545) \\
0.28 \\
\end{array}$ & $\begin{array}{c}1.287 * * * \\
(0.350) \\
0.30 \\
\end{array}$ & $\begin{array}{c}-0.407 \\
(0.440) \\
0.33 \\
\end{array}$ & $\begin{array}{c}0.430 \\
(0.304) \\
0.34 \\
\end{array}$ & $\begin{array}{c}1.566 * * * \\
(0.606) \\
0.39 \\
\end{array}$ & $\begin{array}{c}0.897 \\
(0.822) \\
0.40 \\
\end{array}$ \\
\hline \multicolumn{8}{|l|}{ Math: } \\
\hline Center Care & $\begin{array}{c}0.928 * * * \\
(0.227)\end{array}$ & $\begin{array}{l}1.073 * * \\
(0.486)\end{array}$ & $\begin{array}{c}0.898 * * * \\
(0.305)\end{array}$ & $\begin{array}{c}0.695 \\
(0.561)\end{array}$ & $\begin{array}{l}0.761 * * * \\
(0.280)\end{array}$ & $\begin{array}{l}1.376^{*} \\
(0.708)\end{array}$ & $\begin{array}{l}1.970 * * * \\
(0.671)\end{array}$ \\
\hline 15-30 hours/week, 9 months & $\begin{array}{c}0.769 * * * \\
(0.251)\end{array}$ & $\begin{array}{l}-0.049 \\
(0.674)\end{array}$ & $\begin{array}{c}0.467 \\
(0.371)\end{array}$ & $\begin{array}{l}1.296 * * * \\
(0.401)\end{array}$ & $\begin{array}{c}1.142 * * * \\
(0.300)\end{array}$ & $\begin{array}{l}-0.173 \\
(0.876)\end{array}$ & $\begin{array}{l}-1.112 \\
(0.783)\end{array}$ \\
\hline $\begin{array}{l}\text { At least } 30 \text { hours/week, } 9 \text { months } \\
\text { R-squared }\end{array}$ & $\begin{array}{c}0.704 * * * \\
(0.231) \\
0.37\end{array}$ & $\begin{array}{c}0.794 \\
(0.557) \\
0.29\end{array}$ & $\begin{array}{c}1.036 * * * \\
(0.333) \\
0.30\end{array}$ & $\begin{array}{c}0.165 \\
(0.408) \\
0.32\end{array}$ & $\begin{array}{c}0.625 * * \\
(0.295) \\
0.33\end{array}$ & $\begin{array}{c}0.553 \\
(0.566) \\
0.37\end{array}$ & $\begin{array}{c}1.117 \\
(0.758) \\
0.37\end{array}$ \\
\hline \multicolumn{8}{|l|}{ Behavior: } \\
\hline$\overline{\text { Center Care }}$ & $\begin{array}{l}-0.020 \\
(0.028)\end{array}$ & $\begin{array}{c}-0.122 * * \\
(0.059)\end{array}$ & $\begin{array}{c}0.056 \\
(0.037)\end{array}$ & $\begin{array}{l}-0.088 \\
(0.070)\end{array}$ & $\begin{array}{l}-0.007 \\
(0.034)\end{array}$ & $\begin{array}{l}-0.155 \\
(0.096)\end{array}$ & $\begin{array}{l}-0.051 \\
(0.078)\end{array}$ \\
\hline 15-30 hours/week, 9 months & $\begin{array}{c}-0.102 * * * \\
(0.030)\end{array}$ & $\begin{array}{c}-0.062 \\
(0.082)\end{array}$ & $\begin{array}{c}-0.117 * * * \\
(0.044)\end{array}$ & $\begin{array}{c}-0.123 * * \\
(0.050)\end{array}$ & $\begin{array}{c}-0.119 * * * \\
(0.036)\end{array}$ & $\begin{array}{l}-0.169 \\
(0.119)\end{array}$ & $\begin{array}{c}-0.054 \\
(0.091)\end{array}$ \\
\hline At least 30 hours/week, 9 months & $\begin{array}{c}-0.253 * * * \\
(0.028)\end{array}$ & $\begin{array}{c}-0.088 \\
(0.068)\end{array}$ & $\begin{array}{c}-0.279 * * * \\
(0.040)\end{array}$ & $\begin{array}{c}-0.291 * * * \\
(0.051)\end{array}$ & $\begin{array}{c}-0.287 * * * \\
(0.036)\end{array}$ & $\begin{array}{c}-0.184 * * \\
(0.077)\end{array}$ & $\begin{array}{l}-0.069 \\
(0.088)\end{array}$ \\
\hline R-squared & 0.15 & 0.18 & 0.15 & 0.16 & 0.16 & 0.18 & 0.23 \\
\hline
\end{tabular}

Standard errors in parentheses. * significant at $10 \%$; ** significant at 5\%; *** significant at $1 \%$

Models include child/family and zip code level controls, as well as Head Start dummy and non-relative care dummy (excluded group is parental care). Poor, middle, and high income models include a continuous income to needs variable. 
Table 7: Alternative OLS Estimates of the Effects of "Intense" Center Care on Cognitive and Behavioral Outcomes for the Full Sample

\begin{tabular}{|l|l|l|l|}
\hline & Reading & Math & Behavior \\
\hline center & $0.826^{* *}$ & $0.666^{*}$ & 0.028 \\
\hline $15-30$ hours & $(0.363)$ & $(0.346)$ & $(0.042)$ \\
\hline & $-1.216^{* *}$ & $-1.198^{* *}$ & $-0.149^{* *}$ \\
\hline$>=30$ hours & $(0.573)$ & $(0.545)$ & $(0.066)$ \\
\hline & -0.550 & 0.323 & $-0.341^{* * *}$ \\
\hline nine months or more & $0.555)$ & $(0.528)$ & $(0.064)$ \\
\hline & 0.391 & $0.557^{*}$ & 0.018 \\
\hline $\begin{array}{l}\text { 15-30 hours \& nine } \\
\text { months or more }\end{array}$ & $(0.346)$ & $(0.329)$ & $(0.040)$ \\
\hline & $1.704^{* * *}$ & $1.687^{* * *}$ & -0.015 \\
\hline $\begin{array}{l}>=30 \text { hours \& nine } \\
\text { months or more }\end{array}$ & $(0.632)$ & $(0.602)$ & $(0.073)$ \\
\hline & $1.091^{*}$ & 0.183 & 0.020 \\
\hline R- squared & $0.597)$ & $(0.568)$ & $(0.069)$ \\
\hline
\end{tabular}

